\title{
Potential Roles of Modified Pectin Targeting Galectin-3 against Severe Acute Respiratory Syndrome Coronavirus-2
}

\author{
Frederick Odun-Ayo *(D) and Lalini Reddy *(D) \\ Department of Biotechnology and Consumer Sciences, Faculty of Applied Sciences, Cape Peninsula University of \\ Technology, District Six Campus, Cape Town 7530, South Africa \\ * Correspondence: fredodunayo@gmail.com (F.O.-A.); reddyl@cput.ac.za (L.R.); Tel.: +27-83-382-9455 (L.R.)
}

Citation: Odun-Ayo, F.; Reddy, L. Potential Roles of Modified Pectin Targeting Galectin-3 against Severe Acute Respiratory Syndrome Coronavirus-2. J 2021, 4, 824-837. https://doi.org/10.3390/j4040056

Academic Editor: Jon Øyvind Odland

Received: 15 September 2021

Accepted: 13 October 2021

Published: 29 November 2021

Publisher's Note: MDPI stays neutral with regard to jurisdictional claims in published maps and institutional affiliations.

Copyright: (c) 2021 by the authors. Licensee MDPI, Basel, Switzerland. This article is an open access article distributed under the terms and conditions of the Creative Commons Attribution (CC BY) license (https:/ / creativecommons.org/licenses/by/ $4.0 /)$.

\begin{abstract}
Modified pectin (MP) is a bioactive complex polysaccharide that is broken down into smaller fragments of units and used as an oral dietary supplement for cell proliferation. MP is safe and non-toxic with promising therapeutic properties with regard to targeting galectin-3 (GAL-3) toward the prevention and inhibition of viral infections through the modulation of the immune response and anti-inflammatory cytokine effects. This effect of MP as a GAL-3 antagonism, which has shown benefits in preclinical and clinical models, may be of relevance to the progression of the novel severe acute respiratory syndrome coronavirus-2 (SARS-CoV-2) in coronavirus disease 2019 patients. The outbreak of emerging infectious diseases continues to pose a threat to human health. Further to the circulation of multiple variants of SARS-CoV-2, an effective and alternative therapeutic approach to combat it has become pertinent. The use of MP as a GAL-3 inhibitor could serve as an antiviral agent blocking against the SARS-CoV-2-binding spike protein. This review highlights the potential effects of MP in viral infections, its proposed role as a GAL-3 inhibitor, and the associated function concerning a SARS-CoV-2 infection.
\end{abstract}

Keywords: modified pectin; galectin-3; SARS-CoV-2; polysaccharide; COVID-19; inflammation; immune response

\section{Introduction}

Severe acute respiratory syndrome coronavirus-2 (SARS-CoV-2) emerged as a novel virus in December 2019 in Wuhan, Hubei Province, China, causing the global pandemic coronavirus disease 2019 (COVID-19) [1]. Up to 27 July 2021, a total of about 194 million cases and over 4 million deaths were reported around the world, making COVID-19 a major worldwide health risk [2]. The global public health community faced an imminent need to understand the pathogenesis of the novel coronavirus and produce an effective therapeutic approach to combat its emergence and re-emergence [3]. Several therapies including the antivirals remdesivir and chloroquine have been intensively researched. However, these come with mixed results, lacking a viable standard of treatment for COVID-19 patients [4,5]. Consequently, it has become imperative to identify alternative therapeutic medicines.

SARS-CoV-2 belongs to enveloped RNA viruses, subgenus betacoronavirus of the family coronaviridae [6-8]. SARS-CoV-2 is made up of four primary structural proteins: homotrimer spike (S) glycoprotein, small envelope (E) glycoprotein, membrane (M) glycoprotein and nucleocapsid (N) protein as well as a few ancillary proteins [8]. In coronavirus, the spike proteins (with a distinctive "corona" crown-like shape on the virion surface) have two subunits, the S1 and S2 glycoproteins. S1 has an N-terminal domain (NTD) and a C-terminal domain (CTD), which facilitate the host adhesion binding to the receptor. S2 has a CTD responsible for the fusion of the viral and cellular membranes and the entrance into the cells by attracting angiotensin-converting enzyme 2 (ACE-2) [9,10].

The recent literature has indicated a COVID-19 treatment with a GAL-3-targeted therapy linking the spike proteins of coronaviruses, with human GAL-3 having a similar 
protein structure [11-13]. This involves the use of the GAL-3 inhibitor as an antiviral agent blocking against the SARS-CoV-2-binding spike protein. However, there is still more to explore and understand about this promising GAL-3 target therapy route. Recently, attention has been paid to the potential involvement of pectin as a bioactive complex polysaccharide, which when broken down into smaller fragments is referred to as modified pectin (MP). The antagonistic activity of MP against GAL-3 has been of great interest in the majority of the preclinical and clinical reports in the prevention of and reduction in cancer [14-19] as well as fibrotic, renal injury and cardiovascular diseases [20-23] and inflammatory and immune functions [24-27].

The effects of MP are the subject of new and interesting research with evidence indicating that galactan-rich tiny molecular weight pectin fragments can bind to the carbohydrate recognition domain (CRD) on the pro-metastatic protein, GAL-3. This hinders GAL-3 from interacting with other proteins and peptides, limiting its capacity to stimulate cell adhesion, migration, angiogenesis, tumorigenesis and apoptosis [28-30]. This suggests that MP through the inhibition of GAL-3 could be used in a potentially safe and non-toxic method to prevent or reduce the viral adhesion and viral-associated inflammatory responses targeting a therapeutic approach [13,31]. Given the above, this review looks to highlight the potential effects of MP in viral infections, its proposed role as a GAL-3 inhibitor, and the associated function concerning SARS-CoV-2 infections.

\section{Galectin-3}

GAL-3 is a chimeric carbohydrate-binding protein member of the galectin family. It is a galactose-binding protein that is expressed in numerous human cells including epithelial, endothelial, immunological and inflammatory cells as well as macrophages from the head, neck, thyroid, stomach, brain and alveolar cells in the lungs [32-35]. GAL-3 has a small molecular weight $(30 \mathrm{kDa})$ and comprises three main terminals, namely, the -NH2 terminal domain (NTD), a collagen-like repeated tandem rich of the Gly-Pro-AlaTry protein domain (CPD) and the carbohydrate recognition domain (CRD) containing -COOH terminals and the Asp-Trp-Gly-Arg (NWGR) anti-death motif (Figure 1) [29,36]. The GAL-3 CRD is connected to a long, flexible N-terminal domain with a specific affinity that binds to $\beta$-galactosides such as lactose and larger galacto-oligosaccharides. The $\mathrm{N}$ terminal domain of GAL-3 is required for multimerization and is vulnerable to proteolysis by matrix metalloproteinases and may interact with other intracellular proteins. The interaction of GAL-3 with glycoconjugates containing N-acetyllactosamine is controlled by its C-terminal CRD [37].

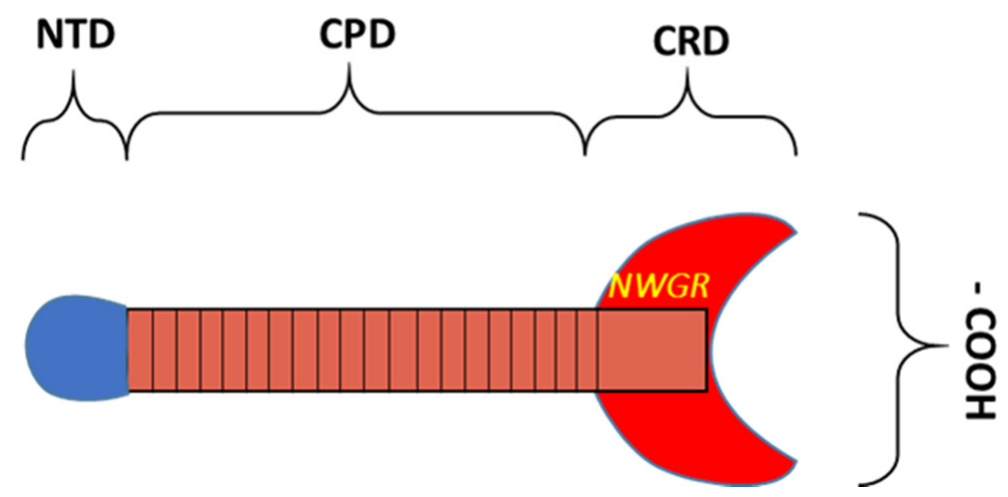

Figure 1. Structure of galectin-3 comprising the -NH2 terminal domain (NTD), the collagen-like protein domain (CPD), consisting of about 100 amino acids, and the carbohydrate recognition domain (CRD), consisting of the -COOH terminal and NWGR.

Recent studies have begun to shed more light on the significance of GAL-3 and its prominent role in viral infections. GAL-3 has been identified as a binding mediator in the entrance and attachment of the herpes simplex virus (HSV) in ocular infection [38]. 
However, it remains unclear whether this holds for the virus at other sites of entry during infection, including the mucosa [31]. During HSV infection, the expression of GAL-3 is increasingly high [39]. Similarly, HIV infection increases GAL-3 expression by activating Toll-like receptor 4 (TLR4)/NF-kB-dependent pathways [40]. GAL-3 is abundantly produced in many infected human T-lymphotropic virus type 1 (HTLV-1) T cells and causes the GAL-3 to be upregulated via HTLV-1 Tax binding to the GAL-3 promoter [41,42]. Endogenous GAL-3 works by interacting intracellularly with the HIV-1 protein Gag and the cellular ALG-2-interacting protein X (Alix), both of which are required for viral budding and replication when new infectious virions are produced [43]. GAL-3 was found to be upregulated in promoting HIV-1 replication in infected CD4 T cells [44].

The endogenous galactoside-binding GAL-3 is implicated in cell growth, as well as cell proliferation, adhesion, differentiation, migration, angiogenesis, mRNA splicing promoter, malignant transformation, and apoptosis [45]. These cellular processes are potential targets to inhibit viral genome replication. Coronaviruses have five primary open reading frames (ORFs) encoded in their genomes which include a $5^{\prime}$ frameshifted polyprotein and four $3^{\prime}$ structural proteins-S, E, M, and N proteins [46]. Potential ORFs implicated in viral genome replication in SARS-CoV-2 and related severe acute respiratory syndrome genomes were investigated using the computer program Gene prediction by Open reading Frame Identification utilizing $X$ motifs [47]. The ORF8b encoded in the SARS-CoV genome promotes the synthesis of cellular DNA and viral replication, as well as the activation of the nucleotide oligomerization domain-like receptor protein 3 (NLRP3) inflammasome [48,49]. Similarly, the activation of the NLRP3 inflammasome by the endogenous GAL-3 increases the severity of avian influenza A H5N1 virus-induced lung inflammation. The lungs of infected mice produced more GAL-3 mRNA protein as a result of influenza virus A H5N1 infection [50]. ORF8b aggregates associated with the GAL-3 cause endoplasmic reticulum and lysosomal stress lead to the nuclear translocation of the transcription factor. The viral genomic RNA triggers TLR to activate the NLRP3 inflammasome [50]. Therefore, the genetic manipulation or inhibition of TLR4 may impede the activation of NLRP3 to reduce the ability of the influenza A virus replication [51] through ORF8b-associated GAL-3 inhibition. This implies that targeting the inhibition of GAL-3 may also affect viral RNA synthesis in the case of the SARS-CoV-2.

The plasma levels of GAL-3 protein were higher in viral infections associated with inflammatory cell infiltration. In hepatitis B infection, the level of GAL-3 may be a useful predictor of chronicity by stimulating CD98 interaction with macrophages to promote the production of certain cytokines and chemokines [52]. The interaction of endogenous GAL-3 with NLRP3 amplifies the impact of H5N1 infection by modulating the production of macrophage IL-1 [50]. In addition, the binding of GAL-3 to influenza virus A promotes pneumococcal adherence to the cell surface [53]. All these indicate that GAL-3 may also have an important role in the primary and secondary airway infections in COVID-19 patients. Although, it is still unclear what causes the increase in GAL-3 in the majority of viral infections. It was suggested that viral gene expression may be driving GAL-3 expression in part $[41,54]$. This multi-functional protein is synthesized in the cytoplasm as a cytosolic protein but can be expressed in the nucleus when transported to the multiple subcellular localization of the cell nucleus, or secreted into the extracellular matrix (ECM) (outside of the cell) $[35,55]$. GAL-3 regulates cell homeostasis both intracellularly and extracellularly [56]. At the extracellular surface, GAL-3 can bind glycoconjugates as an aggregate of cells coming together to form cell-matrix interactions [57].

\section{Modified Pectin}

Pectin is a naturally occurring polysaccharide found in the cell wall of plants such as fruits and vegetables. It is mainly extracted from the citrus peel due to its high concentration in the skin and core parts of the fruit [58]. Pectin is known to be a complex water-soluble polysaccharide composed majorly of: (i) predominant 1,4-linked $\alpha$-D-galacturonic acid of the Rhamnogalacturonan-I (RG-I) region, (ii) a part of the methoxylated-esterified 
carboxyl group structure of the Homogalacturonan (HG) region, which makes it an acidic polysaccharide, and (iii) the Rhamnogalacturonan-II (RG-II) [29]. The RG-I region has more flexibility which is so important because galactan, arabinan, and arabinogalactan side chains are located on the RG-I and attached to the rhamnose residue $[59,60]$. The rhamnose backbone residue is covered in two forms of arabinogalactans: the linear $\beta-(1-4)$-D-galactan and the branched $\beta-(1-3,6)-\mathrm{D}$-galactan. The $\beta-(1-4)-\mathrm{D}$-galactan is most likely a structural weapon with an affinity for binding to the CRD [29].

When MP is originally derived from the citrus fruit, it is then referred to as modified citrus pectin (MCP). MCP is a smaller size uniform fragment of about 10-20 kDa obtained through the effect of $\mathrm{pH}$ modification by alkaline (sodium hydroxide) and/or acid treatment or by enzymatic breakdown [61]. Ordinarily, the degree of esterification in industrial pectin is as high as $70 \%$; it has been defined in MP to be $<10 \%$ by the removal of methoxyl group from the high methoxyl pectin to form low methoxyl pectin. This modification causes the $\beta$-elimination cleavage from the HG backbone, thereby releasing oligomers of polygalacturonic acid. The RG-I region can be further split into galactan and arabinogalactan with fewer arabinose substitutes as the treatment cleaves linkages between the neutral sugars and eventually modifies the RG-I (Figure 2) [62,63]. This modification produces unique bioactivity in $\mathrm{MCP}$ which creates a chance for the carboxyl group on the galactan to interact more with GAL-3 and increases the bioavailability of the free galactans that bind to the GAL-3 [63].

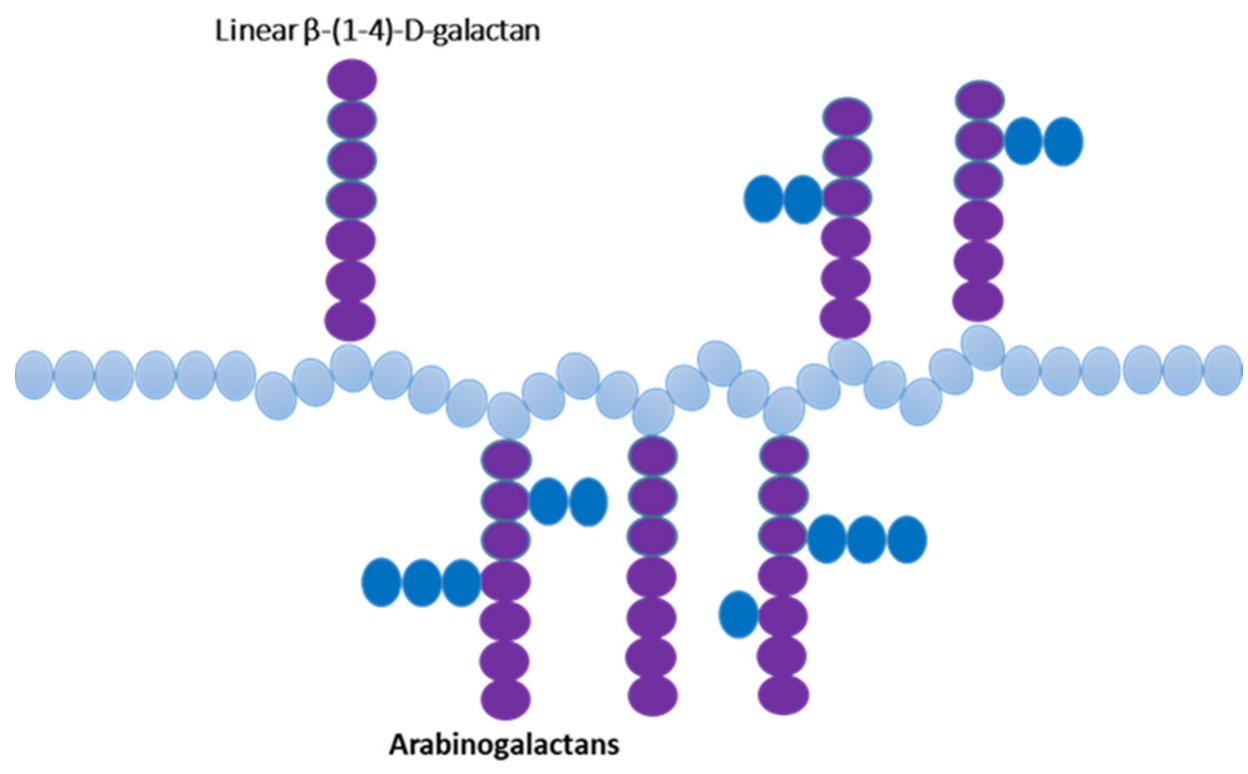

Figure 2. Schematic diagram of modified pectin RG-I consisting of the linear $\beta-(1-4)-D-g a l a c t a n$ and the arabinogalactans residues after the enzymatic treatment cleaves the sugars linkage in pectin [29].

$\mathrm{MCP}$ is rich in $\beta$-galactose, potentially safe, and non-toxic. It is used as a dietary supplement to promote cell growth. Recent research has linked the effects of the oral consumption of MCP to its specific molecular interaction with the GAL-3. Studies have shown the health benefits of MP, highlighting the roles of targeting the inhibition of GAL-3 in immune response, inflammation, macrophages, cytokines, cardiovascular, renal injury, fibrosis, and cognitive impairment [28]. Most of these studies have given considerable focus to the effect of MCP with significant preclinical and clinical trials in vivo and in vitro. This has demonstrated reliable outcomes to justify the health benefit and acceptable safety profile of the MCP. Although, to date, there is little or no information on the role of MP targeting viral infections, particularly toward GAL-3 inhibition. However, it is plausible to extrapolate the potential role of pectin and its impact on COVID-19 infection. 


\section{Potential Role of Modified Pectin Binding Galectin-3 in SARS-CoV-2 Infections}

Studies have shown the potential role of industrial pectin in exploring its antiviral activity (Table 1). In most MCP research, GAL-3 plays several prominent roles which influence its bioactivity by inducing extracellular functions such as the interaction between cells and inflammation. The relevance of the effect of MP through GAL-3 antagonism to the progression of SARS-CoV-2 in COVID-19 patients can be extrapolated from the perspective of (i) MP and GAL-3 binding as a mediator for viral adhesion in the virus infection mechanism through the viral spike protein, given that the $\mathrm{N}$-terminal domain of SARS-CoV-2 evolves from a galectin origin, (ii) MP and GAL-3 response to inflammation and macrophage driving the cytokine storm in severe SARS-CoV-2 cases.

Table 1. Antiviral effect of pectin on various viral infections.

\begin{tabular}{|c|c|c|c|c|}
\hline Disease Indication & Model of Study & Virus & Outcome of Study & References \\
\hline COVID-19 & Molecular docking & SARS-CoV-2 & $\begin{array}{l}\text { Citrus pectin binding to the protein } \\
\text { receptor inhibits the replication of } \\
\text { the SARS-CoV-2. }\end{array}$ & {$[64]$} \\
\hline COVID-19 & Molecular docking & SARS-CoV-2 & $\begin{array}{l}\text { Citrus specific binding to the ACE-2 } \\
\text { inhibits the replication of } \\
\text { SARS-CoV-2. }\end{array}$ & [65] \\
\hline Mosaic disease & Plant & Tobacco Mosaic Virus & $\begin{array}{l}\text { MP mediated virus-induced gene } \\
\text { generates short interfering silencing } \\
\text { of viral RNA and spread. }\end{array}$ & {$[66,67]$} \\
\hline Mosaic disease & Plant & Tobacco Mosaic Virus & $\begin{array}{l}\text { Pectin methylesterase suppresses } \\
\text { the transport of viral protein in } \\
\text { antisense plants. }\end{array}$ & [68] \\
\hline Genital Herpes & In vitro & $\begin{array}{l}\text { Herpes Simplex Virus } \\
\text { Type } 1 \text { and Poliovirus }\end{array}$ & $\begin{array}{l}\text { Pectin inhibits viral replication by } \\
\text { binding to the glycoprotein and } \\
\text { carboxyl groups on the cell } \\
\text { membrane. }\end{array}$ & [69] \\
\hline Hepatitis & In vitro & Hepatitis B Virus & $\begin{array}{l}\text { Pectin (SLP-4) inhibits the secretion } \\
\text { of surface and envelope antigens of } \\
\text { HBV in HepG2 cells through pectin } \\
\text { polysaccharide and HBV protein } \\
\text { interaction. }\end{array}$ & {$[70]$} \\
\hline Influenza & Mouse & Influenza A Virus & $\begin{array}{l}\text { MCP induces Th1 T-helper immune } \\
\text { response. }\end{array}$ & {$[71,72]$} \\
\hline Genital Herpes & In vitro & $\begin{array}{l}\text { Herpes Simplex Virus } \\
\text { Type } 2\end{array}$ & $\begin{array}{l}\text { Pectin polysaccharide shows an } \\
\text { anti-HSV-2 activity. }\end{array}$ & [73] \\
\hline
\end{tabular}

Abbreviations: COVID-19: Coronavirus disease 2019, SARS-CoV-2: Severe acute respiratory syndrome coronavirus-2, ACE-2; Angiotensinconverting enzyme 2, MP: Modified pectin, MCP: Modified citrus pectin.

\subsection{Modified Pectin and Galectin-3 Binding against a Viral Adhesion}

GAL-3 has been identified as a binding mediator that aids viral attachment. In SARSCoV-2 infection, the glycosylation of the outer membrane spike glycoprotein causes the interaction of the viral protein with the cell receptors and adhesion factors, including ACE-2. It was hypothesized that the unique N- and O-linked glycosylation sites of the S1NTD spike glycoprotein in SARS-CoV-2 may interact with immunoregulatory factors [74]. This suggests that GAL-3 plays an important role in SARS-CoV-2 host interaction [13]. NTD and CTD domains can function as receptor-binding domains (RBDs). The S1-NTDs are in charge of sugar-binding, recognizing both $\mathrm{N}$-acetylneuraminic acid (Neu5Ac) and $\mathrm{N}$ glycolylneuraminic acid (Neu5Gc) sugar receptors [75-77] and the S1-CTDs detect ACE-2 protein receptor $[78,79]$. It is noteworthy that a recent study reveals a dual interaction of S1NTD binding to the sugar co-receptor, Neu5Ac [75] and the ACE-2 receptor in SARS-CoV-2 
infection. The negatively charged - $\mathrm{COOH}$ terminal of the 9-O-acetyl-Neu5Ac is positioned for interaction with available sugar or protein molecules [80,81].

SARS-CoV-2 may be able to recognize Neu5Ac co-receptors besides the ACE-2 by acquiring the GTNGTKR motif on the S1-NTD [82]. In extreme cases of SARS-CoV-2, a new type of sialic acid-linked ganglioside-binding domain was discovered at the $\mathrm{S}$ protein's N-terminal domain [82]. It is therefore noteworthy that SARS-CoV-2 binds to Neu5Ac, GAL-3, GTNGTKR motif, and sialic acids-linked ganglioside could contribute to the greater infectivity of the virus compared to the SARS-CoV $[75,82,83]$. Similarly, the abundance of Neu5Ac and GAL-3 receptors in the human body particularly at the nasopharynx and oral mucosa has been noted compared to the ACE-2 receptors [83]. This could contribute to the high transmissibility and infectivity of SARS-CoV-2, particularly at viral entry points $[32,34]$.

Recent studies have reported a high degree of similarity in the NTD receptor-binding domain of different coronaviruses, as well as similarity in the structural alignment of the S1-NTD and GAL-3 of SARS-CoV-2 [82]. This indicates that both Neu5Ac and GAL3 receptors may have similar $-\mathrm{COOH}$ terminal domains. The terminal galactose in the neutral sugar side chain of the polysaccharide enables MP to bind specifically to GAL-3 CRD [84]. GAL-3 CRD has an affinity for $\beta$-galactosides and MP is a sugar molecule with an abundance of $\beta$-galactose [85]. This enables MP to antagonize the GAL-3 $\beta$-galactoside protein by binding tightly to it and modulate its bioactivity [86]. It is reasonable to assume that the $\beta-1,4$-galactan of the neutral sugar chain in MP has the potential affinity to bind specifically to the - $\mathrm{COOH}$ terminal of the Neu5Ac and/or GAL-3 receptors. This inhibits the attachment of the S1-NTD of SARS-CoV-2 to the host cell (Figure 3). Although, a detailed investigation of the mechanisms involving GAL-3 binding and/or inhibition by MP will provide a means of testing this molecular hypothesis and identifying the particular pectin-derived components responsible for the effects.

The knowledge of antiviral compounds containing sugar or sugar analogs that may be used to prevent coronavirus from attaching to its sugar co-receptor [78] has led to unraveling the antiviral potential of pectin and related flavonoids. A study has shown that plants can protect themselves against virus infection by silencing virus-induced genes stimulated by pectin methylesterase [87]. This suggests that pectin methylesterase may contain compounds that mediate the prevention of viral infection in their host. A pectin polysaccharide from a plant named 'Portulaca oleracea' containing galacturonic acid, galactose, and glucose with small amounts of arabinose and rhamnose showed significant inhibition against herpes simplex virus type 2 (HSV-2) with a selectivity index of more than 20 [73]. Similarly, pectin has high inhibitory effects of $179 \mu \mathrm{g} / \mathrm{mL}^{-1}$ and $58 \mu \mathrm{g} / \mathrm{mL}^{-1}$ against herpes simplex virus type 1 (HSV-1) and the poliovirus, respectively in Hep-2 cells [69]. This further suggests that the interaction of pectin with the cation amino acids glycoprotein-binding site in HSV-1 and the anion sulfated/carboxyl group heparin-sulfate chains of the cell membrane impedes viral initiation and replication at the initial early stage $[69,88]$.

The $S$ glycoprotein on the NTD is the major antigen on the viral surface that neutralizing antibodies can attack during an infection, hence preventing viral entry $[89,90]$. It is pertinent to mention that the attachment of SARS-CoV-2 to the cell surface for replication through viral spike protein has multiple potential therapeutic targets. Although the relationship between GAL-3 and SARS-CoV-2 is also mixed, it is still unclear if it is pro- and/or anti-SARS-CoV-2. Furthermore, investigating the possibility of having similarities in the molecular structure of S1-NTD and MP could decipher the potential of a direct binding affinity of the sugar galactan to the CRD of SARS-CoV-2. This will provide an understanding of the interaction of $\mathrm{N}$ - and O-linked glycosylation sites of the spike glycoprotein with the carboxyl group on the MP galactan CRD in SARS-CoV-2 infection.

Some natural bioactive compounds and flavonoids such as hesperidin and hesperetin which are related to citrus pectin have demonstrated the potency of the antiviral effect. Hesperidin in citrus peel contains a very interesting molecule with potential antiviral activity against SARS-CoV-2 [91]. Studies reported that the inhibitory activities of hesperidin 
against SARS-CoV-2 are through its binding affinity to the protease domain, the ACE-2 receptor-binding domain, and the spike glycoprotein receptor-binding domain $[64,92,93]$. Hesperetin binds to the receptor domain by inhibiting the attachment of SARS-CoV-2 to the ACE-2 receptor [65]. Further study revealed that citrus hesperidin and hesperetin have the highest binding affinity to the SARS-CoV-2 receptors spike glycoprotein (S1-NTD), protease, and ACE-2 by showing the lowest dock scoring, which indicates a high inhibitory potential against the viral infection and replication [64].

Extracellular

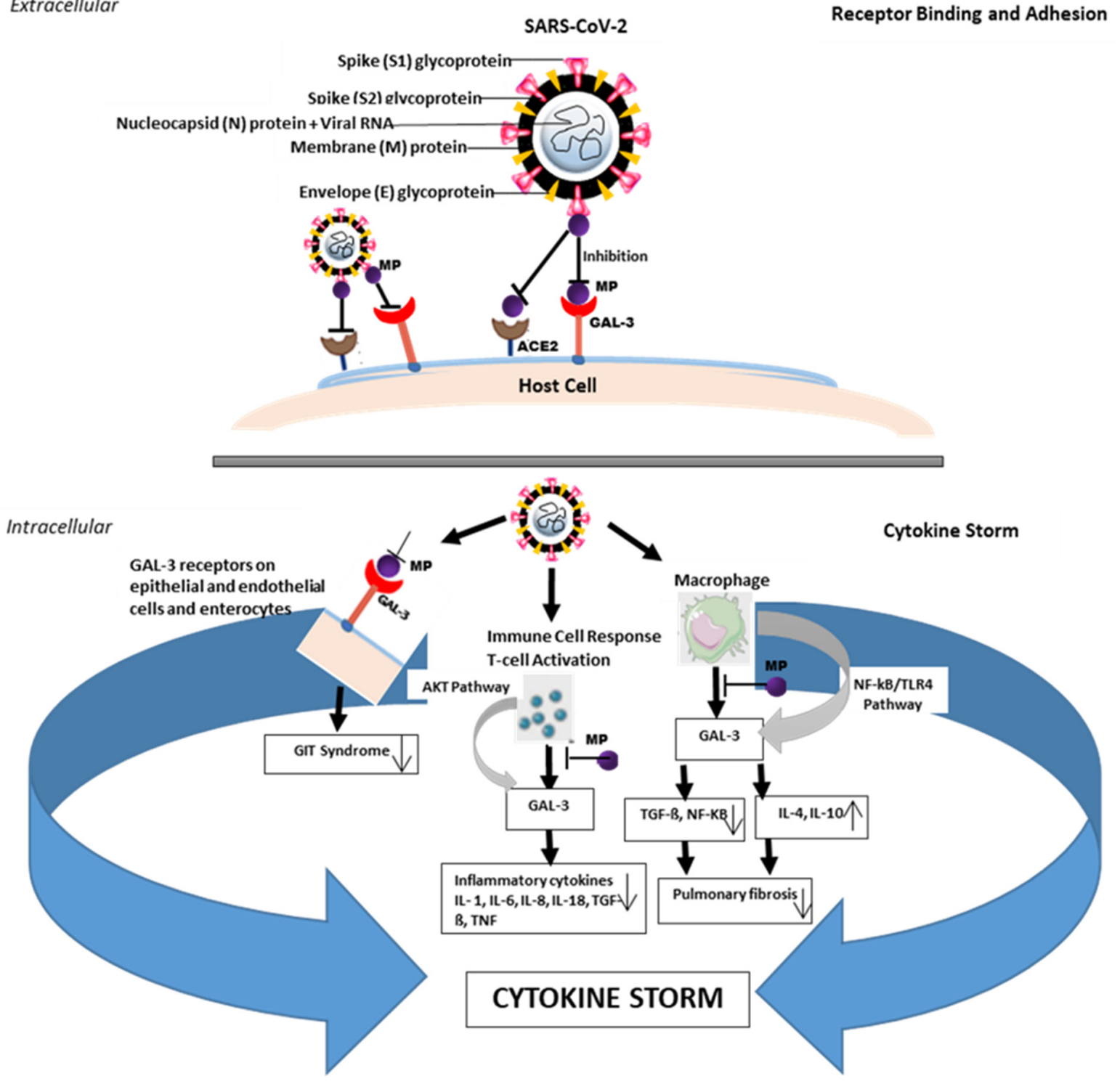

Figure 3. Effect of modified pectin (MP) associated with galectin-3 (GAL-3) during severe SARS-CoV-2 infection. Receptor binding and adhesion: MP binds to the GAL-3 receptor to inhibit SARS-CoV-2 attachment and adhesion to the host cell surface. During severe SARS-CoV-2 infection, the activation of T cell immune response through AKT and NF-KB/TLR4 pathways induces the release of GAL-3 and increase inflammatory cytokines such as interleukins (IL-1, IL-6, IL-8, IL-18) in circulating macrophages and monocytes, resulting in a feedback loop that may contribute to the development of the cytokine storm. This elevates the levels of TGF- $B$ and NF-KB, leading to pulmonary fibrosis. MP binds GAL-3 at the initiation and/or activation of the immune response stage, epithelial membranes, endothelial, and enterocytes to inhibit cytokine feedback and also prevents gastrointestinal tract (GIT) syndrome. GAL-3 inhibition by MP prevents or reduces the release and/or levels of the inflammatory cytokines which contributes to preventing pulmonary fibrosis. 


\subsection{Modified Pectin and Galectin-3 Response to the Cytokine Storm Effect}

According to studies, cytokine inhibition is one of the best therapeutic methods for COVID-19 depending on the stage of infection in the patient. It was further suggested that therapies aimed at reducing hyper inflammation and lung damage should be administered at the severe (pneumonia) stage [94,95]. Based on the human immune response against SARS-CoV-2 infection, changes in T lymphocytes subsets (lymphopenia) accompanied by the cytokine storm syndrome contribute to the progression of the disease and poor prognosis. During this period, lymphopenia is commonly observed with an increase in IL-6 and other inflammatory cytokines (pneumonia phase). Acute lung injury, high initial viral titers, and macrophage/neutrophil build-up in the lungs are all symptoms of severe SARS-CoV-2 infection, as well as a high level of pro-inflammatory cytokines such as the interleukins IL-1, -6, -8, -18 and monocyte chemotactic protein-3 in the blood [96].

Patients with severe COVID-19 have significantly higher levels of GAL-3, tumor necrosis factor (TNF), IL-1, and IL-6 than those with moderate disease [97,98]. Furthermore, GAL-3 regulates and possibly causes a dysregulated pattern of these pro-inflammatory cytokine expressions during infection through the AKT signaling pathways [53]. Consequently, the inhibition of GAL-3 greatly reduces the level of these cytokines, which suggests that it could be useful in lowering the inflammatory consequences of COVID-19 [97,99]. Secreted GAL-3 produced by macrophages during injury promotes the upregulation and elevated level of TGF- $\beta$ receptors, leading to pulmonary fibrosis (fibroblast activation), observed to be one of the major complications of SARS-CoV-2 infection $[100,101]$. The inhibition of GAL-3 has been shown to reduce adenovirus-induced lung fibrosis [102]. Thus, it is worthwhile to investigate MP as a potential treatment through its GAL-3 inhibition for pulmonary fibrotic-related diseases including severe cases in COVID-19.

The unique anti-inflammatory bioactivity of MP in humans being connected to the sugar $\beta$-galactose-inhibiting cell signaling protein, GAL-3, is responsible for tumor cell proliferation and metastasis [29]. This stimulates or modulates intestinal homeostasis and also plays a role in immunological modulation [103]. Although GAL-3 inhibits the inflammatory response of the intestinal system via the GALT, which modulates macrophage signaling recruitment [104], it can as well bind to cell surface receptors to create a clustering effect [57]. Consequently, a higher concentration of GAL-3 at this binding site activates $\mathrm{T}$ cells with a possible evasion of the immune surveillance system. The initiation of MP binding to GAL-3 in addition to the possible Neu5Ac interaction linked to the ganglioside domain on the epithelial cell surface may inhibit the extracellular matrix interactions.

The RNA of SARS-CoV-2 has been presented in the gastrointestinal tracts and stool samples of COVID-19 patients [105-107]. This implies that SARS-CoV-2 can infiltrate enterocytes and serve as a virus reservoir [107]. It is noteworthy that a rising number of SARS-CoV-2 patients have reported the possible indication of gastrointestinal symptoms including diarrhea (2.0-10.1\%), nausea and vomiting (1.0-3.6\%), and abdominal pain in COVID-19 patients $[108,109]$. Most of these patients infected with SARS-CoV-2 have mild gastrointestinal symptoms and a good prognosis after the infection indicates that the immune function is a strong defense against this virus. The SARS-CoV-2 binds to the ACE-2 receptors which are highly expressed on alveolar cells of the lungs, upper esophagus, and stratified epithelial cells, as well as other cells such as absorptive enterocytes from the ileum and colon, myocardial cells, and kidney proximal tubule cells [110]. This explains why, in some cases, COVID-19 patients not only experience respiratory problems but also disorders of the heart, kidneys, and digestive tract [111].

In our previous studies, we reported the initiation of MCP and adhesion of probiotic bacteria to specific receptors on the epithelial cell surface of the colon to inhibit the extracellular matrix interactions of GAL-3 [17]. We further showed that MCP alginate supplemented with a probiotic, Lactobacillus acidophilus ATCC 4356, significantly increases fecal lactobacilli and improves the integrity of intestinal microbiota [25,112]. As a result, the synthesized extracellular macromolecules also contribute to modulating the immune response $[113,114]$. During the adhesion of microbiomes at the site, MCP modifies their 
functionality and physiological properties in the gut which causes the reduction and prevention of GIT syndromes. The gut microbiome has a significant influence on systemic and distant immune responses at the mucosal sites such as the lungs $[115,116]$. Certain probiotic strains help prevent bacterial and viral infections such as gastroenteritis, sepsis, and respiratory tract infections. The administration of certain strains of Bifidobacterium and Lactobacilli aided the clearance of the influenza virus from the respiratory tract with minimal inflammatory damage to the lung tissue [116]. This is influenced by the ability of the probiotic strains to modulate a systematic balance between pro-inflammatory and anti-inflammatory immunoregulatory cytokines. In a randomized control trial study conducted on upper respiratory tract-infected middle-aged patients, a probiotic with Lactobacillus plantarum DR7 reduces plasma IFN- $\gamma$ and TNF- $\alpha$ pro-inflammatory cytokines, as well as stimulates the increases in IL-4 and IL-10 anti-inflammatory cytokines [117].

Further evidence has shown the influence of MCP on immunomodulatory activities for the regulation of inflammatory cytokines. MCP upregulates the level of IL-4, an antiinflammatory cytokine in the spleen of treated BALB/c mice [24]. The stimulation of this cytokine might be of particular relevance to COVID-19 patients in preventing complications of acute respiratory distress syndrome. MCP inhibits MAP kinase activation, increases the expression level of downstream target Bim (a pro-apoptotic protein), and induces the cleavage of Caspase-3 in PC3 and Caspase-1.1 [118]. Its ability modulates the immune response, T helper cells, pro-inflammatory cytokines (IL-17, IFN- $\gamma$, and TNF- $\alpha$ levels), and anti-inflammatory cytokines (IL-4 and IL-10) [24]. MCP induces the Th1 T-helper immune response in murine influenza vaccination and allergic asthma models [71,72]. This selectively stimulates $\mathrm{T}$ cytotoxic and $\mathrm{NK}$ cell responses, as attributed to the presence of a low degree of methyl esterification in MCP [27]. Pectin polysaccharides from natural plants cell walls may modulate immunity against SARS-CoV-2 through the release of cytokines such as TNF- $\alpha$ and IL-6, anti-inflammatory activity, and the increased phagocytosis of macrophages. Additionally, they may achieve this through the production of nitrous oxide, reactive oxygen species formation, and activation of signaling pathways including Toll-like 4, type A hijacker receptor, NF-kB, and glucan receptor $[119,120]$.

\section{Conclusions and Future Directions}

With the understanding that there is a global health emergency to curb the high mortality and morbidity caused by COVID-19, the repositioning of drugs and alternative therapies may be a new option for the treatment of SARS-CoV-2 infection. Evidence has shown emerging MP as one of the most promising and naturally occurring anti-GAL-3 substances. A novel approach using a GAL-3 inhibitor highlights a potential therapeutic target against SARS-CoV-2 infection. MP has shown the potential of the GAL-3 inhibitor in disease progression and new benefits of this bioactive compound will continuously be unraveled. The bioactive effect of MP against GAL-3 is a promising treatment target against SARS-CoV-2 infection. However, it is important to mention that this would be a new area of research that will help understand that MPs are likely to interfere with the initial attachment of viral particles to the surface epithelium of the respiratory tract.

Despite evidence from numerous studies that MP inhibits various steps in cell-cell interactions, fibrotic, renal injury, and cardiovascular diseases by interacting with GAL-3, the details of the underlying mechanisms are still largely unknown. Although pectin-derived galactan binds specifically to GAL-3, the precise structural characteristics responsible for the optimal binding to GAL-3 causing pro-inflammatory mechanisms associated with immune modulation remain unknown. As variants of SARS-CoV-2 are evolving, the virus may switch in binding sites to new receptors, from the firstly known ACE-2 to newly discovered ones as in the case of GAL-3. This implies that virus inhibitors at the attachment and entry stage are key to mitigating SARS-CoV-2 replication in the host cell; hence, the quick development of these inhibitors should suffice. Despite a few uncertainties, there is a good level of tolerance with regard to the safety and non-toxic acceptance of MP oral consumption, with evidence that dietary and citrus pectin polysaccharide RGI fragments 
have a positive effect and good prognosis on some viral infections in vitro. Its potential to benefit COVID-19 patients by regulating the immune response system is a possibility yet to be determined; hence, both in vitro and in vivo studies should be explored.

Author Contributions: F.O.-A. and L.R. conceived the study. F.O.-A. performed the literature search and wrote the manuscript. F.O.-A. and L.R. contributed to the critical review of the manuscript and approval for submission. All authors have read and agreed to the published version of the manuscript.

Funding: This research was funded by the Research, Technology, Innovation and Partnerships of Cape Peninsula University of Technology (CPUT).

Institutional Review Board Statement: Not applicable.

Informed Consent Statement: Not applicable.

Data Availability Statement: Not applicable.

Acknowledgments: The authors would like to thank the Research, Technology, Innovation and Partnerships Department of CPUT for the support and postdoctoral opportunity.

Conflicts of Interest: The authors declare no conflict of interest.

\section{References}

1. Lu, H.; Stratton, C.W.; Tang, Y.W. Outbreak of pneumonia of unknown etiology in Wuhan, China: The mystery and the miracle. J. Med. Virol. 2020, 92, 401. [CrossRef]

2. World Health Organization. COVID-19 weekly epidemiological update, edition 45. 22 June 2021. Available online: https://www. who.int/publications/m/item/weekly-epidemiological-update-on-covid-19---22-june-2021 (accessed on 14 September 2021).

3. Gao, G.F. From "A" IV to "Z" IKV: Attacks from emerging and re-emerging pathogens. Cell 2018, 172, 1157-1159. [CrossRef]

4. Ko, W.-C.; Rolain, J.-M.; Lee, N.-Y.; Chen, P.-L.; Huang, C.-T.; Lee, P.-I.; Hsueh, P.-R. Arguments in favour of remdesivir for treating SARS-CoV-2 infections. Int. J. Antimicrob. Agents 2020, 55, 105933. [CrossRef]

5. Zhai, P.; Ding, Y.; Wu, X.; Long, J.; Zhong, Y.; Li, Y. The epidemiology, diagnosis and treatment of COVID-19. Int. J. Antimicrob. Agents 2020, 55, 105955. [CrossRef]

6. Andersen, K.G.; Rambaut, A.; Lipkin, W.I.; Holmes, E.C.; Garry, R.F. The proximal origin of SARS-CoV-2. Nat. Med. 2020, 26, 450-452. [CrossRef]

7. Gorbalenya, A.E.; Baker, S.C.; Baric, R.S.; de Groot, R.J.; Drosten, C.; Gulyaeva, A.A.; Haagmans, B.; Lauber, C.; Leontovich, A.; Neuman, B. Coronaviridae Study Group of the International Committee on Taxonomy of Viruses. The species severe acute respiratory syndrome-related coronavirus: Classifying 2019-nCoV and naming it SARS-CoV-2. Nat. Microbiol. 2020, 5, 536-544.

8. Lu, R.; Zhao, X.; Li, J.; Niu, P.; Yang, B.; Wu, H.; Wang, W.; Song, H.; Huang, B.; Zhu, N. Genomic characterisation and epidemiology of 2019 novel coronavirus: Implications for virus origins and receptor binding. Lancet 2020, 395, 565-574. [CrossRef]

9. Belouzard, S.; Millet, J.K.; Licitra, B.N.; Whittaker, G.R. Mechanisms of coronavirus cell entry mediated by the viral spike protein. Viruses 2012, 4, 1011-1033. [CrossRef]

10. Li, F. Structure, function, and evolution of coronavirus spike proteins. Annu. Rev. Virol. 2016, 3, 237-261. [CrossRef]

11. Caniglia, J.L.; Asuthkar, S.; Tsung, A.J.; Guda, M.R.; Velpula, K.K. Immunopathology of galectin-3: An increasingly promising target in COVID-19. F1000Res 2020, 9, 1-18. [CrossRef]

12. Caniglia, J.L.; Guda, M.R.; Asuthkar, S.; Tsung, A.J.; Velpula, K.K. A potential role for Galectin-3 inhibitors in the treatment of COVID-19. PeerJ 2020, 8, e9392. [CrossRef]

13. Garcia-Revilla, J.; Deierborg, T.; Venero, J.L.; Boza-Serrano, A. Hyperinflammation and fibrosis in severe COVID-19 patients: Galectin-3, a target molecule to consider. Front. Immunol. 2020, 11, 2069. [CrossRef] [PubMed]

14. Fang, T.; Liu, D.-D.; Ning, H.-M.; Liu, D.; Sun, J.-Y.; Huang, X.-J.; Dong, Y.; Geng, M.-Y.; Yun, S.-F.; Yan, J. Modified citrus pectin inhibited bladder tumor growth through downregulation of galectin-3. Acta Pharmacol. Sin. 2018, 39, 1885-1893. [CrossRef] [PubMed]

15. Hossein, G.; Halvaei, S.; Heidarian, Y.; Dehghani-Ghobadi, Z.; Hassani, M.; Hosseini, H.; Naderi, N.; Sheikh Hassani, S. Pectasol-C Modified Citrus Pectin targets Galectin-3-induced STAT3 activation and synergize paclitaxel cytotoxic effect on ovarian cancer spheroids. Cancer Med. 2019, 8, 4315-4329. [CrossRef]

16. Li, H.-Y.; Yang, S.; Li, J.-C.; Feng, J.-X. Galectin 3 inhibition attenuates renal injury progression in cisplatin-induced nephrotoxicity. Biosci. Rep. 2018, 38, BSR20181803. [CrossRef]

17. Odun-Ayo, F.; Mellem, J.; Naicker, T.; Reddy, L. Chemoprevention of azoxymethane-induced colonic carcinogenesis in Balb/c mice using a modified pectin alginate probiotic. Anticancer Res. 2015, 35, 4765-4775. [PubMed]

18. Wang, S.; Li, P.; Lu, S.-M.; Ling, Z.-Q. Chemoprevention of low-molecular-weight citrus pectin (LCP) in gastrointestinal cancer cells. Int. J. Biol. Sci. 2016, 12, 746. [CrossRef]

19. Wu, K.-L.; Kuo, C.-M.; Huang, E.-Y.; Pan, H.-M.; Huang, C.-C.; Chen, Y.-F.; Hsiao, C.-C.; Yang, K.D. Extracellular galectin-3 facilitates colon cancer cell migration and is related to the epidermal growth factor receptor. Am. J. Transl. Res. 2018, 10, 2402. 
20. Fernandez-García, C.-E.; Tarin, C.; Roldan-Montero, R.; Martinez-Lopez, D.; Torres-Fonseca, M.; Lindhot, J.S.; Vega de Ceniga, M.; Egido, J.; Lopez-Andres, N.; Blanco-Colio, L.-M. Increased galectin-3 levels are associated with abdominal aortic aneurysm progression and inhibition of galectin-3 decreases elastase-induced AAA development. Clin. Sci. 2017, 131, 2707-2719. [CrossRef]

21. Li, S.; Li, S.; Hao, X.; Zhang, Y.; Deng, W. Perindopril and a galectin-3 inhibitor improve ischemic heart failure in rabbits by reducing Gal-3 expression and myocardial fibrosis. Front. Physiol. 2019, 10, 267. [CrossRef]

22. Lu, Y.; Zhang, M.; Zhao, P.; Jia, M.; Liu, B.; Jia, Q.; Guo, J.; Dou, L.; Li, J. Modified citrus pectin inhibits galectin-3 function to reduce atherosclerotic lesions in apoE-deficient mice. Mol. Med. Rep. 2017, 16, 647-653. [CrossRef]

23. Martínez-Martínez, E.; Brugnolaro, C.; Ibarrola, J.; Ravassa, S.; Buonafine, M.; López, B.; Fernández-Celis, A.; Querejeta, R.; Santamaria, E.; Fernández-Irigoyen, J. CT-1 (Cardiotrophin-1)-Gal-3 (Galectin-3) Axis in cardiac fibrosis and inflammation: Mechanistic insights and clinical implications. Hypertension 2019, 73, 602-611. [CrossRef]

24. Merheb, R.; Abdel-Massih, R.M.; Karam, M.C. Immunomodulatory effect of natural and modified citrus pectin on cytokine levels in the spleen of BALB/c mice. Int. J. Biol. Macromol. 2019, 121, 1-5. [CrossRef]

25. Odun-Ayo, F.; Mellem, J.; Reddy, L. Improving the survival of probiotic in simulated conditions and azoxymethane-induced colon tumour bearing mice using modified citrus pectin-alginate microencapsulation. Afr. J. Tradit. Complement. Altern. Med. 2016, 13, 101-109. [CrossRef]

26. Ramachandran, C.; Wilk, B.; Melnick, S.J.; Eliaz, I. Synergistic antioxidant and anti-inflammatory effects between modified citrus pectin and honokiol. Evid. Based Complement. Altern. Med. 2017, 2017, 1-9. [CrossRef]

27. Ramachandran, C.; Wilk, B.J.; Hotchkiss, A.; Chau, H.; Eliaz, I.; Melnick, S.J. Activation of human T-helper/inducer cell, Tcytotoxic cell, B-cell, and natural killer (NK)-cells and induction of natural killer cell activity against K562 chronic myeloid leukemia cells with modified citrus pectin. BMC Complement. Altern. Med. 2011, 11,1-9. [CrossRef] [PubMed]

28. Eliaz, I.; Raz, A. Pleiotropic effects of modified citrus pectin. Nutrients 2019, 11, 2619. [CrossRef]

29. Maxwell, E.G.; Belshaw, N.J.; Waldron, K.W.; Morris, V.J. Pectin-an emerging new bioactive food polysaccharide. Trends Food Sci. Technol. 2012, 24, 64-73. [CrossRef]

30. Nangia-Makker, P.; Hogan, V.; Raz, A. Galectin-3 and cancer stemness. Glycobiology 2018, 28, 172-181. [CrossRef]

31. Machala, E.A.; McSharry, B.P.; Rouse, B.T.; Abendroth, A.; Slobedman, B. Gal power: The diverse roles of galectins in regulating viral infections. J. Gen. Virol. 2019, 100, 333-349. [CrossRef]

32. Díaz-Alvarez, L.; Ortega, E. The many roles of galectin-3, a multifaceted molecule, in innate immune responses against pathogens. Mediat. Inflamm. 2017, 2017, 1-10. [CrossRef] [PubMed]

33. Liu, F.T.; Rabinovich, G.A. Galectins: Regulators of acute and chronic inflammation. Ann. N. Y. Acad. Sci. 2010, 1183, 158-182. [CrossRef] [PubMed]

34. Reyfman, P.A.; Walter, J.M.; Joshi, N.; Anekalla, K.R.; McQuattie-Pimentel, A.C.; Chiu, S.; Fernandez, R.; Akbarpour, M.; Chen, C.-I.; Ren, Z. Single-cell transcriptomic analysis of human lung provides insights into the pathobiology of pulmonary fibrosis. Am. J. Respir. Crit. Care Med. 2019, 199, 1517-1536. [CrossRef] [PubMed]

35. Yu, L.-G. Circulating galectin-3 in the bloodstream: An emerging promoter of cancer metastasis. World J. Gastrointest. Oncol. 2010, 2, 177. [CrossRef]

36. Harazono, Y.; Nakajima, K.; Raz, A. Why anti-Bcl-2 clinical trials fail: A solution. Cancer Metastasis Rev. 2014, 33, 285-294. [CrossRef]

37. Newlaczyl, A.U.; Yu, L.-G. Galectin-3-a jack-of-all-trades in cancer. Cancer Lett. 2011, 313, 123-128. [CrossRef]

38. Woodward, A.; Mauris, J.; Argüeso, P. Binding of transmembrane mucins to galectin-3 limits herpesvirus 1 infection of human corneal keratinocytes. J. Virol. 2013, 87, 5841-5847. [CrossRef]

39. King, R.D.; Lubinski, J.M.; Friedman, H.M. Herpes simplex virus type 1 infection increases the carbohydrate binding activity and the secretion of cellular galectin-3. Arch. Virol. 2009, 154, 609-618. [CrossRef]

40. Okamoto, M.; Hidaka, A.; Toyama, M.; Baba, M. Galectin-3 is involved in HIV-1 expression through NF-kB activation and associated with Tat in latently infected cells. Virus Res. 2019, 260, 86-93. [CrossRef]

41. Hsu, D.K.; Hammes, S.R.; Kuwabara, I.; Greene, W.C.; Liu, F.-T. Human T lymphotropic virus-I infection of human T lymphocytes induces expression of the beta-galactoside-binding lectin, galectin-3. Am. J. Pathol. 1996, 148, 1661.

42. Wang, W.-H.; Lin, C.-Y.; Chang, M.R.; Urbina, A.N.; Assavalapsakul, W.; Thitithanyanont, A.; Chen, Y.-H.; Liu, F.-T.; Wang, S.-F. The role of galectins in virus infection-A systemic literature review. J. Microbiol. Immunol. Infect. 2020, 53, 925-935. [CrossRef]

43. Wang, S.-F.; Tsao, C.-H.; Lin, Y.-T.; Hsu, D.K.; Chiang, M.-L.; Lo, C.-H.; Chien, F.-C.; Chen, P.; Arthur Chen, Y.-M.; Chen, H.-Y. Galectin-3 promotes HIV-1 budding via association with Alix and Gag p6. Glycobiology 2014, 24, 1022-1035. [CrossRef]

44. Kulkarni, R.; Prasad, A. Exosomes derived from HIV-1 infected DCs mediate viral trans-infection via fibronectin and galectin-3. Sci. Rep. 2017, 7, 1-14. [CrossRef]

45. Yang, R.-Y.; Rabinovich, G.A.; Liu, F.-T. Galectins: Structure, function and therapeutic potential. Expert Rev. Mol. 2008, 10, 1-24. [CrossRef]

46. Ashour, H.M.; Elkhatib, W.F.; Rahman, M.; Elshabrawy, H.A. Insights into the recent 2019 novel coronavirus (SARS-CoV-2) in light of past human coronavirus outbreaks. Pathogens 2020, 9, 186. [CrossRef]

47. Michel, C.J.; Mayer, C.; Poch, O.; Thompson, J.D. Characterization of accessory genes in coronavirus genomes. Virol. J. 2020, 17, 1-13. [CrossRef] 
48. Shi, C.-S.; Nabar, N.R.; Huang, N.-N.; Kehrl, J.H. SARS-Coronavirus Open Reading Frame-8b triggers intracellular stress pathways and activates NLRP3 inflammasomes. Cell Death Discov. 2019, 5, 1-12. [CrossRef]

49. Yue, Y.; Nabar, N.R.; Shi, C.-S.; Kamenyeva, O.; Xiao, X.; Hwang, I.-Y.; Wang, M.; Kehrl, J.H. SARS-Coronavirus Open Reading Frame-3a drives multimodal necrotic cell death. Cell Death Dis. 2018, 9, 1-15. [CrossRef]

50. Chen, Y.-J.; Wang, S.-F.; Weng, I.-C.; Hong, M.-H.; Lo, T.-H.; Jan, J.-T.; Hsu, L.-C.; Chen, H.-Y.; Liu, F.-T. Galectin-3 enhances avian H5N1 influenza a virus-induced pulmonary inflammation by promoting NLRP3 inflammasome activation. Am. J. Pathol. 2018, 188, 1031-1042. [CrossRef]

51. Dai, J.-P.; Wang, Q.-W.; Su, Y.; Gu, L.-M.; Deng, H.-X.; Chen, X.-X.; Li, W.-Z.; Li, K.-S. Oxymatrine inhibits influenza A virus replication and inflammation via TLR4, p38 MAPK and NF-kB pathways. Int. J. Mol. Sci. 2018, 19, 965. [CrossRef]

52. Uluca, Ü.; Şen, V.; Ece, A.; Tan, İ.; Karabel, D.; Aktar, F.; Karabel, M.; Balık, H.; Güneş, A. Serum galectin-3 levels in children with chronic hepatitis B infection and inactive hepatitis B carriers. Med. Sci. Monit. Int. Med. J. Exp. Clin. Res. 2015, $21,1376$.

53. Nita-Lazar, M.; Banerjee, A.; Feng, C.; Vasta, G.R. Galectins regulate the inflammatory response in airway epithelial cells exposed to microbial neuraminidase by modulating the expression of SOCS1 and RIG1. Mol. Immunol. 2015, 68, 194-202. [CrossRef]

54. Fogel, S.; Guittaut, M.; Legrand, A.; Monsigny, M.; Hébert, E. The tat protein of HIV-1 induces galectin-3 expression. Glycobiology 1999, 9, 383-387. [CrossRef]

55. Hill, M.; Mazal, D.; Biron, V.A.; Pereira, L.; Ubillos, L.; Berriel, E.; Ahmed, H.; Freire, T.; Rondán, M.; Vasta, G.R. A novel clinically relevant animal model for studying galectin-3 and its ligands during colon carcinogenesis. J. Histochem. Cytochem. 2010, 58, 553-565. [CrossRef]

56. Demetter, P.; Nagy, N.; Martin, B.; Mathieu, A.; Dumont, P.; Decaestecker, C.; Salmon, I. The galectin family and digestive disease. J. Pathol. 2008, 215, 1-12. [CrossRef]

57. Yang, R.-Y.; Hsu, D.K.; Liu, F.-T. Expression of galectin-3 modulates T-cell growth and apoptosis. Proc. Natl. Acad. Sci. USA 1996, 93, 6737-6742. [CrossRef]

58. Srivastava, P.; Malviya, R. Sources of pectin, extraction and its applications in pharmaceutical industry-An overview. Indian J. Nat. Prod. Resour. 2011, 2, 10-18.

59. Yapo, B.M. Pineapple and banana pectins comprise fewer homogalacturonan building blocks with a smaller degree of polymerization as compared with yellow passion fruit and lemon pectins: Implication for gelling properties. Biomacromolecules 2009, 10, 717-721. [CrossRef]

60. Yapo, B.M. Pectic substances: From simple pectic polysaccharides to complex pectins-A new hypothetical model. Carbohydr. Polym. 2011, 86, 373-385. [CrossRef]

61. Eliaz, I. The potential role of modified citrus pectin in the prevention of cancer metastasis. Clin. Pract. Altern. Med. 2001, 2, 177-180.

62. Diaz, J.V.; Anthon, G.E.; Barrett, D.M. Nonenzymatic degradation of citrus pectin and pectate during prolonged heating: Effects of $\mathrm{pH}$, temperature, and degree of methyl esterification. J. Agric. Food Chem. 2007, 55, 5131-5136. [CrossRef]

63. Morris, V.J. Pectin galactans, galectins and health Bioactive roles for pectin. Agro. Food Ind. Hi Tech. 2009, 20, 37-40.

64. Utomo, R.Y.; Meiyanto, E. Revealing the potency of citrus and galangal constituents to halt SARS-CoV-2 infection. Preprints 2020, 2020, 1-8.

65. Chen, H.; Qh, D. Potential Natural Compounds for Preventing 2019-ncoV Infection. 10 March 2020. Available online: https: //www.preprints.org/manuscript/202001.0358/v1 (accessed on 14 September 2021).

66. Bubici, G.; Carluccio, A.V.; Cillo, F.; Stavolone, L. Virus-induced gene silencing of pectin methylesterase protects Nicotiana benthamiana from lethal symptoms caused by Tobacco mosaic virus. Eur. J. Plant. Pathol. 2015, 141, 339-347. [CrossRef]

67. Dorokhov, Y.L.; Frolova, O.Y.; Skurat, E.V.; Ivanov, P.A.; Gasanova, T.V.; Sheveleva, A.A.; Ravin, N.V.; Mäkinen, K.M.; Klimyuk, V.I.; Skryabin, K.G. A novel function for a ubiquitous plant enzyme pectin methylesterase: The enhancer of RNA silencing. FEBS Lett. 2006, 580, 3872-3878. [CrossRef]

68. Chen, M.H.; Citovsky, V. Systemic movement of a tobamovirus requires host cell pectin methylesterase. Plant. J. 2003, 35, 386-392. [CrossRef] [PubMed]

69. de Godoi, A.M.; Faccin-Galhardi, L.C.; Rechenchoski, D.Z.; Arruda, T.B.M.G.; Cunha, A.P.; de Almeida, R.R.; Rodrigues, F.E.A.; Ricardo, N.M.P.S.; Nozawa, C.; Linhares, R.E.C. Structural characterization and antiviral activity of pectin isolated from Inga spp. Int. J. Biol. Macromol. 2019, 139, 925-931. [CrossRef]

70. Chen, W.; Zhu, X.; Ma, J.; Zhang, M.; Wu, H. Structural elucidation of a novel pectin-polysaccharide from the petal of Saussurea laniceps and the mechanism of its Anti-HBV Activity. Carbohydr. Polym. 2019, 223, 115077. [CrossRef]

71. Vos, A.P.; Haarman, M.; VanGinkel, J.W.H.; Knol, J.; Garssen, J.; Stahl, B.; Boehm, G.; M’Rabet, L. Dietary supplementation of neutral and acidic oligosaccharides enhances Th1-dependent vaccination responses in mice. Pediatr. Allergy Immunol. 2007, 18, 304-312. [CrossRef] [PubMed]

72. Vos, A.v.; Van Esch, B.; Stahl, B.; M'rabet, L.; Folkerts, G.; Nijkamp, F.; Garssen, J. Dietary supplementation with specific oligosaccharide mixtures decreases parameters of allergic asthma in mice. Int. Immunopharmacol. 2007, 7, 1582-1587. [CrossRef] [PubMed]

73. Dong, C.-X.; Hayashi, K.; Lee, J.-B.; Hayashi, T. Characterization of structures and antiviral effects of polysaccharides from Portulaca oleracea L. C Chem. Pharm. Bull. 2010, 58, 507-510. [CrossRef] [PubMed] 
74. Vankadari, N.; Wilce, J.A. Emerging COVID-19 coronavirus: Glycan shield and structure prediction of spike glycoprotein and its interaction with human CD26. Emerg. Microbes Infect. 2020, 9, 601-604. [CrossRef]

75. Baker, A.N.; Richards, S.-J.; Guy, C.S.; Congdon, T.R.; Hasan, M.; Zwetsloot, A.J.; Gallo, A.; Lewandowski, J.R.; Stansfeld, P.J.; Straube, A. The SARS-COV-2 spike protein binds sialic acids and enables rapid detection in a lateral flow point of care diagnostic device. ACS Cent. Sci. 2020, 6, 2046-2052. [CrossRef]

76. Schultze, B.; Krempl, C.; Ballesteros, M.L.; Shaw, L.; Schauer, R.; Enjuanes, L.; Herrler, G. Transmissible gastroenteritis coronavirus, but not the related porcine respiratory coronavirus, has a sialic acid (N-glycolylneuraminic acid) binding activity. J. Virol. 1996, 70, 5634-5637. [CrossRef] [PubMed]

77. Schwegmann-Weßels, C.; Herrler, G. Sialic acids as receptor determinants for coronaviruses. Glycoconj. J. 2006, 23, 51-58. [CrossRef]

78. Liu, C.; Tang, J.; Ma, Y.; Liang, X.; Yang, Y.; Peng, G.; Qi, Q.; Jiang, S.; Li, J.; Du, L. Receptor usage and cell entry of porcine epidemic diarrhea coronavirus. J. Virol. 2015, 89, 6121-6125. [CrossRef] [PubMed]

79. Promkuntod, N.; Van Eijndhoven, R.; De Vrieze, G.; Gröne, A.; Verheije, M. Mapping of the receptor-binding domain and amino acids critical for attachment in the spike protein of avian coronavirus infectious bronchitis virus. Virol 2014, 448, 26-32. [CrossRef]

80. Fantini, J.; Di Scala, C.; Chahinian, H.; Yahi, N. Structural and molecular modelling studies reveal a new mechanism of action of chloroquine and hydroxychloroquine against SARS-CoV-2 infection. Int. J. Antimicrob. Agents 2020, 55, 105960. [CrossRef] [PubMed]

81. Kim, C.-H. SARS-CoV-2 evolutionary adaptation toward host entry and recognition of receptor O-Acetyl sialylation in virus-host interaction. Int. J. Mol. Sci. 2020, 21, 4549. [CrossRef]

82. Behloul, N.; Baha, S.; Shi, R.; Meng, J. Role of the GTNGTKR motif in the N-terminal receptor-binding domain of the SARS-CoV-2 spike protein. Virus Res. 2020, 286, 198058. [CrossRef]

83. Barnard, K.N.; Wasik, B.R.; LaClair, J.R.; Buchholz, D.W.; Weichert, W.S.; Alford-Lawrence, B.K.; Aguilar, H.C.; Parrish, C.R. Expression of 9-O-and 7, 9-O-acetyl modified sialic acid in cells and their effects on influenza viruses. MBio 2019, 10, e02490-19. [CrossRef]

84. Gunning, A.P.; Bongaerts, R.J.; Morris, V.J. Recognition of galactan components of pectin by galectin-3. FASEB J. 2009, 23, 415-424 [CrossRef] [PubMed]

85. Glinsky, V.V.; Raz, A. Modified citrus pectin anti-metastatic properties: One bullet, multiple targets. Carbohydr. Res. 2009, 344, 1788-1791. [CrossRef]

86. Gao, X.; Zhi, Y.; Zhang, T.; Xue, H.; Wang, X.; Foday, A.D.; Tai, G.; Zhou, Y. Analysis of the neutral polysaccharide fraction of MCP and its inhibitory activity on galectin-3. Glycoconj. J. 2012, 29, 159-165. [CrossRef] [PubMed]

87. Lionetti, V.; Cervone, F.; Bellincampi, D. Methyl esterification of pectin plays a role during plant-pathogen interactions and affects plant resistance to diseases. J. Plant. Physiol. 2012, 169, 1623-1630. [CrossRef] [PubMed]

88. Dong, C.-X.; Hayashi, K.; Mizukoshi, Y.; Lee, J.-B.; Hayashi, T. Structures and anti-HSV-2 activities of neutral polysaccharides from an edible plant, Basella Rubra L. Int. J. Biol. Macromol. 2012, 50, 245-249. [CrossRef] [PubMed]

89. Chi, X.; Yan, R.; Zhang, J.; Zhang, G.; Zhang, Y.; Hao, M.; Zhang, Z.; Fan, P.; Dong, Y.; Yang, Y. A neutralizing human antibody binds to the N-terminal domain of the Spike protein of SARS-CoV-2. Science 2020, 369, 650-655. [CrossRef]

90. Tortorici, M.A.; Walls, A.C.; Lang, Y.; Wang, C.; Li, Z.; Koerhuis, D.; Boons, G.-J.; Bosch, B.-J.; Rey, F.A.; de Groot, R.J. Structural basis for human coronavirus attachment to sialic acid receptors. Nat. Struct. Mol. Biol. 2019, 26, 481-489. [CrossRef]

91. Meneguzzo, F.; Ciriminna, R.; Zabini, F.; Pagliaro, M. Review of evidence available on hesperidin-rich products as potential tools against COVID-19 and hydrodynamic cavitation-based extraction as a method of increasing their production. Processes 2020, 8 , 549. [CrossRef]

92. Tallei, T.E.; Tumilaar, S.G.; Niode, N.J.; Kepel, B.J.; Idroes, R.; Effendi, Y.; Sakib, S.A.; Emran, T.B. Potential of plant bioactive compounds as SARS-CoV-2 main protease (Mpro) and spike (S) glycoprotein inhibitors: A molecular docking study. Scientifica 2020, 2020, 1-18. [CrossRef]

93. Wu, C.; Liu, Y.; Yang, Y.; Zhang, P.; Zhong, W.; Wang, Y.; Wang, Q.; Xu, Y.; Li, M.; Li, X. Analysis of therapeutic targets for SARS-CoV-2 and discovery of potential drugs by computational methods. Acta Pharm. Sin. B 2020, 10, 766-788. [CrossRef] [PubMed]

94. Lin, L.; Lu, L.; Cao, W.; Li, T. Hypothesis for potential pathogenesis of SARS-CoV-2 infection-a review of immune changes in patients with viral pneumonia. Emerg. Microbes Infect. 2020, 9, 727-732. [CrossRef] [PubMed]

95. Shi, Y.; Wang, Y.; Shao, C.; Huang, J.; Gan, J.; Huang, X.; Bucci, E.; Piacentini, M.; Ippolito, G.; Melino, G. COVID-19 infection: The perspectives on immune responses. Cell Death Differ. 2020, 27, 1451-1454. [CrossRef] [PubMed]

96. Yang, Y.; Shen, C.; Li, J.; Yuan, J.; Yang, M.; Wang, F.; Li, G.; Li, Y.; Xing, L.; Peng, L. Exuberant elevation of IP-10, MCP-3 and IL-1ra during SARS-CoV-2 infection is associated with disease severity and fatal outcome. J. Allergy Clin. Immunol. 2020, 146, 119-127. [CrossRef]

97. De Biasi, S.; Meschiari, M.; Gibellini, L.; Bellinazzi, C.; Borella, R.; Fidanza, L.; Gozzi, L.; Iannone, A.; Tartaro, D.L.; Mattioli, M. Marked T cell activation, senescence, exhaustion and skewing towards TH17 in patients with COVID-19 pneumonia. Nat. Commun. 2020, 11, 1-17. [CrossRef] 
98. Wang, J.; Jiang, M.; Chen, X.; Montaner, L.J. Cytokine storm and leukocyte changes in mild versus severe SARS-CoV-2 infection: Review of 3939 COVID-19 patients in China and emerging pathogenesis and therapy concepts. J. Leukoc. Biol. 2020, 108, 17-41. [CrossRef]

99. Kalfaoglu, B.; Almeida-Santos, J.; Tye, C.A.; Satou, Y.; Ono, M. T-cell hyperactivation and paralysis in severe COVID-19 infection revealed by single-cell analysis. Front. Immunol. 2020, 11, 2605. [CrossRef]

100. Delpino, M.; Quarleri, J. SARS-CoV-2 pathogenesis: Imbalance in the renin-angiotensin system favors lung fibrosis. Front. Cell. Infect. Microbiol. 2020, 10, 340. [CrossRef]

101. Xia, S.; Liu, M.; Wang, C.; Xu, W.; Lan, Q.; Feng, S.; Qi, F.; Bao, L.; Du, L.; Liu, S. Inhibition of SARS-CoV-2 (previously 2019-nCoV) infection by a highly potent pan-coronavirus fusion inhibitor targeting its spike protein that harbors a high capacity to mediate membrane fusion. Cell Res. 2020, 30, 343-355. [CrossRef]

102. Saito, S.; Alkhatib, A.; Kolls, J.K.; Kondoh, Y.; Lasky, J.A. Pharmacotherapy and adjunctive treatment for idiopathic pulmonary fibrosis (IPF). J. Thorac. Dis. 2019, 11 (Suppl. 14), S1740. [CrossRef] [PubMed]

103. Sánchez, B.; Ruiz, L.; Gueimonde, M.; Ruas-Madiedo, P.; Margolles, A. Toward improving technological and functional properties of probiotics in foods. Trends Food Sci. Technol. 2012, 26, 56-63. [CrossRef]

104. Rice, P.J.; Adams, E.L.; Ozment-Skelton, T.; Gonzalez, A.J.; Goldman, M.P.; Lockhart, B.E.; Barker, L.A.; Breuel, K.F.; DePonti, W.K.; Kalbfleisch, J.H. Oral delivery and gastrointestinal absorption of soluble glucans stimulate increased resistance to infectious challenge. J. Pharmacol. Exp. Ther. 2005, 314, 1079-1086. [CrossRef] [PubMed]

105. Jin, X.; Lian, J.-S.; Hu, J.-H.; Gao, J.; Zheng, L.; Zhang, Y.-M.; Hao, S.-R.; Jia, H.-Y.; Cai, H.; Zhang, X.-L. Epidemiological, clinical and virological characteristics of 74 cases of coronavirus-infected disease 2019 (COVID-19) with gastrointestinal symptoms. Gut 2020, 69, 1002-1009. [CrossRef]

106. Lin, L.; Jiang, X.; Zhang, Z.; Huang, S.; Zhang, Z.; Fang, Z.; Gu, Z.; Gao, L.; Shi, H.; Mai, L. Gastrointestinal symptoms of 95 cases with SARS-CoV-2 infection. Gut 2020, 69, 997-1001. [CrossRef]

107. Pan, Y.; Zhang, D.; Yang, P.; Poon, L.L.; Wang, Q. Viral load of SARS-CoV-2 in clinical samples. Lancet Infect. Dis. 2020, $20,411-412$. [CrossRef]

108. Chen, N.; Zhou, M.; Dong, X.; Qu, J.; Gong, F.; Han, Y.; Qiu, Y.; Wang, J.; Liu, Y.; Wei, Y. Epidemiological and clinical characteristics of 99 cases of 2019 novel coronavirus pneumonia in Wuhan, China: A descriptive study. Lancet 2020, 395, 507-513. [CrossRef]

109. Wang, D.; Hu, B.; Hu, C.; Zhu, F.; Liu, X.; Zhang, J.; Wang, B.; Xiang, H.; Cheng, Z.; Xiong, Y. Clinical characteristics of 138 hospitalized patients with 2019 novel coronavirus-infected pneumonia in Wuhan, China. JAMA 2020, 323, 1061-1069. [CrossRef]

110. Xu, H.; Zhong, L.; Deng, J.; Peng, J.; Dan, H.; Zeng, X.; Li, T.; Chen, Q. High expression of ACE2 receptor of 2019-nCoV on the epithelial cells of oral mucosa. Int. J. Oral Sci. 2020, 12, 1-5. [CrossRef]

111. Astuti, I. Severe Acute Respiratory Syndrome Coronavirus 2 (SARS-CoV-2): An overview of viral structure and host response. Diabetes Metab. Syndr. Clin. Res. Rev. 2020, 14, 407-412. [CrossRef]

112. Odun-Ayo, F.; Mellem, J.; Reddy, L. The effect of modified citrus pectin-probiotic on faecal lactobacilli in Balb/c mice. Food Sci. Technol. 2017, 37, 478-482. [CrossRef]

113. Liu, C.F.; Tseng, K.C.; Chiang, S.S.; Lee, B.H.; Hsu, W.H.; Pan, T.M. Immunomodulatory and antioxidant potential of Lactobacillus exopolysaccharides. J. Sci. Food Agric. 2011, 91, 2284-2291. [CrossRef] [PubMed]

114. Ruas-Madiedo, P.; Medrano, M.; Salazar, N.; De Los Reyes-Gavilán, C.; Pérez, P.F.; Abraham, A.G. Exopolysaccharides produced by Lactobacillus and Bifidobacterium strains abrogate in vitro the cytotoxic effect of bacterial toxins on eukaryotic cells. J. Appl. Microbiol. 2010, 109, 2079-2086. [CrossRef] [PubMed]

115. Abt, M.C.; Osborne, L.C.; Monticelli, L.A.; Doering, T.A.; Alenghat, T.; Sonnenberg, G.F.; Paley, M.A.; Antenus, M.; Williams, K.L.; Erikson, J. Commensal bacteria calibrate the activation threshold of innate antiviral immunity. Immunity 2012, 37, 158-170. [CrossRef]

116. Zelaya, H.; Alvarez, S.; Kitazawa, H.; Villena, J. Respiratory antiviral immunity and immunobiotics: Beneficial effects on inflammation-coagulation interaction during influenza virus infection. Front. Immunol. 2016, 7, 633. [CrossRef]

117. Chong, H.-X.; Yusoff, N.A.A.; Hor, Y.-Y.; Lew, L.-C.; Jaafar, M.H.; Choi, S.-B.; Yusoff, M.S.; Wahid, N.; Abdullah, M.F.I.; Zakaria, N. Lactobacillus plantarum DR7 improved upper respiratory tract infections via enhancing immune and inflammatory parameters: A randomized, double-blind, placebo-controlled study. J. Dairy Sci. 2019, 102, 4783-4797. [CrossRef]

118. Yan, J.; Katz, A. PectaSol-C modified citrus pectin induces apoptosis and inhibition of proliferation in human and mouse androgen-dependent and-independent prostate cancer cells. Integr. Cancer Ther. 2010, 9, 197-203. [CrossRef] [PubMed]

119. Barbosa, J.R.; de Carvalho Junior, R.N. Polysaccharides obtained from natural edible sources and their role in modulating the immune system: Biologically active potential that can be exploited against COVID-19. Trends Food Sci. Technol. 2021, 108, $223-235$. [CrossRef]

120. Iravani, S.; Varma, R.S. Important Roles of Oligo-and Polysaccharides against SARS-CoV-2: Recent Advances. Appl. Sci. 2021, 11, 3512. [CrossRef] 